Www.jmscr.igmpublication.org Impact Factor 5.84

Index Copernicus Value: 83.27

ISSN (e)-2347-176x ISSN (p) 2455-0450

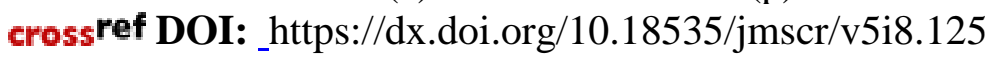

Journal Of Medical Science And Clinical Research

IGM Publication

An official Publication of IGM Publication

\title{
Raised Platelets Distribution Width as a Risk Assessment Prognostic Tool For Post Myocardial Infarction Patients
}

Author

Dr M.S.Koolwal

Corresponding Author

Dr M.S.Koolwal

Email-madhusudan.koolwall@gmail.com

\begin{abstract}
Objectives \& Aims: The evaluation and identify new prognostic markers suggested in recent studies for coronary heart disease, raised platelets distribution width (PDW) has been found to be associated with poor prognosis after resent myocardial infarction. Evaluate the relationship between raised PDW and mortality morbidity after the initial attack of myocardial infarction (MI). Increased platelets distribution width (PDW) has been associated with adverse outcomes. We studied the association between raised PDW during hospital course with clinical outcomes survival index of patients with after acute myocardial infarction (AMI).

Material \& Methods: Blood was collected in a sterile EDTA containing tube and processed following our established iso certified hospital based laboratory protocol. A complete blood counting including HB\%, PCV, Red cell indices, platelet count, total white cell count and PDW was done by Automated blood cell counter. Level of Troponin I done by automated mini vidas bioanalyser.

Conclusion: we find significantly correlation in patients with post MI along with high PDW. PDW is an inexpensive cost effective and easily available laboratory test, high PDW with high troponin I for post MI have poor outcome of patients' it could be used for mortality with morbidity risk assessment and follow up the patients after MI .we find that high PDW of raised troponin I pt. shows poor prognosis. confirmation of mi done by troponin I level of every patients.

Keyword: myocardial infarction, platelets distribution width.
\end{abstract}

\section{Material \& Methods}

Study area and design- This present study was conducted at the Advanced institute of medical sciences and research Bhopal and associated referral hospital Bhopal mp. The study was designed as a observational retrograde with prospective hospital based study over a period of time from 2016.

Ethical consideration- Blood was collected in a sterile EDTA tube and plaint tube and processed following our established laboratory protocol then generate the report of each patient. Take informed consent was obtained from all study participant for use of your blood sample for medical research after doing physician request investigating and generate the report.

Patient's selection criteria-The study target all patients on the basis of clinical signs, symptoms and ECG ST elevation with high troponin I level, history by attainder. We include both emergency and IPD patients with all age groups, male and female both gender for study. Sample size is 100 patients. 
Laboratory investigations Blood was collected in a sterile EDTA containing tube and processed following our established laboratory protocol .A complete blood counting including $\mathrm{HB} \%, \mathrm{PCV}$, Red cell indices, platelet count and total white cell count and differential was done by Automated blood cell counter and peripheral blood smear examination. The all cell count indices including RBC, WBC count with differential along with morphological changes further confirmed by manual oil immersion smear study method. Peripheral smears study was done with field A and B stain and leishman stain.

\section{Red Cells Distribution Width and Peripheral Smear}

\section{Materials}

Purple vacutainer tube or capillary collector (EDTA) ethylenediaminetetraacetate, Slides and blue capillary tube, Needle or lancet, Vacutainer holder, Alcohol swab, Cotton balls, Absorbent materials,Slide case and heamatological cell counter. and second sample in clot activator tube for serum troponin I by automated bioanalyser.

\section{Procedure}

Specimen is collected into EDTA(purple) vacutainer. ( 5 or $7 \mathrm{ml}$ volume)

Then the run the sample in hematological cell counter and generate PDW data.

The PDW median was $13.3 \%$, with a reference range of $10.0 \%-17.9 \%$ for the 5th-95th percentiles, with a confidence interval of $95 \%$. Normal range 9-13fL.

Serological troponin I is done by minividas methods

\section{Obervation \& Discussion}

\begin{tabular}{|c|l|l|l|l|}
\hline $\begin{array}{l}\text { RDW- } \\
\mathrm{CV}\end{array}$ & Prognosis & $\begin{array}{l}\text { Survival } \\
\text { outcome } \\
\text { of patients }\end{array}$ & $\begin{array}{l}\text { Serological } \\
\text { troponin I }\end{array}$ & $\begin{array}{l}\text { Sample } \\
\text { size } \\
\mathrm{N}=100\end{array}$ \\
\hline $\begin{array}{c}>13 \text { to } \\
<14 \mathrm{fL}\end{array}$ & Mild & Good & $\begin{array}{l}>100 \mathrm{TO} \\
1000 \mathrm{ng} / \mathrm{L}\end{array}$ & 66 \\
\hline $\begin{array}{c}>14 \text { to } \\
<15 \mathrm{fL}\end{array}$ & Moderate & Average & $\begin{array}{l}>1000 \mathrm{TO} \\
5000 \mathrm{ng} / \mathrm{L}\end{array}$ & 24 \\
\hline $\begin{array}{c}>15 \text { to } \\
<16 \mathrm{fL}\end{array}$ & Sever & Poor & $\begin{array}{l}>5000 \mathrm{TO} \\
10000 \mathrm{ng} / \mathrm{L}\end{array}$ & 08 \\
\hline$>16 \mathrm{Fl}$ & Marked & Worst & $\begin{array}{l}>10000 \\
\mathrm{ng} / \mathrm{L}\end{array}$ & 02 \\
\hline
\end{tabular}

\section{Result}

Univariate analysis showed that there were significant associations of high PDW values with, the acute coronary artery disease, mild to marked type toxicity these various morphological changes cause the raised platelets distribution width use as a prognostic tool for survival index outcome of patients. Kruskal-Wallis tests revealed an association of raised PDW values with severity survival index patients: $p<0.0001$, survival prognostic index of patients with higher PDW values had poorer worst prognoses than those with normal RDW values (Wilcoxon test: $p=0.002$ ). multivariate analysis showed higher PDW is a significant prognostic factor $(p=0.040)$.

\section{Conclusionion}

Our study is, to the best of our knowledge, the first to demonstrate an association between PDW and serum troponin I risk of incident $\mathrm{MI}$ in a general population. The association was consistent when PDW was modeled both as continuous and categorical variables, and the risk of MI by RDW correlation with troponin $\mathrm{i}$ pattern. The presence of anemia did not affect the risk estimates. Survival of patients is easily find with PDW and troponin I correlation.

There are only a few previous reports on the relation between PDW and troponin I for post MI patients from general populations. A strong association between higher PDW and high level of troponin I with post MI poor outcome high mortality was found is our study. ${ }^{13}-14$ The risk of MI death increased by $22 \%$ for a $1-$ SD increment of PDW (HR 1.22; 95\% CI, 1.14 to 1.31$)^{\frac{14}{4}}$ and was more than 2-fold higher among participants in the highest quintile compared with the lowest. ${ }^{13}$, the risk of post MI mortility events increased 39\% among patients with P DW of $16 \%$ to $17 \%$ (HR 1.39 ; $95 \% \mathrm{CI}, 1.24$ to 1.57 ) compared with patients with RDW with normal range $\% .{ }^{19}$ In contrast, PDW is associated with MI (HR 1.05; $95 \%$ CI, 0.65 to 1.68 ) or myocardial mortality (HR 1.09; 95\% CI, 0.96 to 1.23 ) in this study. Greater power to detect a significant association between PDW and risk of MI in our study may be 
the main reason for the apparent discrepant relationship between PDW and serum troponin I for post MI .

The mechanism for the observed association between PDW and post MI morbidity and mortality now a day settled. Because PDW is a statistical concept, it can be assumed that PDW is a marker of other underlying biological mechanisms.

PDW is suggested to be a biomarker reflecting a proinflammatory condition. Oxidative stress and inflammation increase PDW by impairing iron metabolism, The stronger association between PDW and serum troponin I for post MI in our study supports the suggestion that PDW reflects inflammation. Others have also speculated that the biological link between PDW and post MI mortality may be mediated by systemic inflammation. It has been reported that increased post MI mortality by PDW is confined to those with anemia. we included hemoglobin in our multivariable model and performed analyses in which anemic participants were excluded. The risk estimates for MI by PDW in our study were not affected by adjustment for hemoglobin or by excluding participants with anemia. This demonstrates that anemia does not explain the strong association between PDW and MI. Furthermore, results from association between extremely high PDW (>16fl).

Platelet distribution width (PDW) Platelet distribution width shows the heterogenosity in the size of platelets and is derived from the platelet indices from an automated analyzer. The reference range in a study done by Mariela Graniro Farias was derived as $13.3 \%$ as median with a reference range of $10 \%$ to $17.9 \%$. Platelet distribution width is a marker of platelet reactivity ${ }^{[30]}$. When laser technology is used in an analyzer it primarily detects the cross diameter of the cell to derive its volume. Machines using impedance principle focus on the vertical diameter of the cell to asses the cell's size. Whatever may be the technique used, activated platelets will be larger and is not dependent on the technique of analysis ${ }^{[31]}$.
Role of platelets in coronary artery heart disease Whenever there is a stressful situation, the platelets that are produced are larger in size and they posses a very high potential for thrombus formation since they produce more thromboxane B2 . During situations of platelet activation both MPV and PDW increase. This change is hypothesized due to the change in platelet shape from that of discoid to spherical shape to attain larger surface area. These changes can be analyzed by the hematology analyzers that works on the impedance principle discussed already. Platelet activation is a very essential step in the production and propagation of the process of atherothrombosis ${ }^{[32]}$. The platelet parameters like MPV and PDW are independent risk parameters in Myocardial Infarction (MI) and stroke indicating worse clinical course and mortality ${ }^{[33]}$. ST-segment Elevation Myocardial Infarction (STEMI) and failure of thrombolysis is influenced by high PDW values. Also it has been studied that PDW is higher in patients with STEMI rather than stable Coronary Artery Disease (CAD). Rather than just association they also influence the success of thrombolysis in STEMI patients ${ }^{\text {[34] }}$

There are several studies which analysed the risk of Platelet Distribution Width (PDW) in acute coronary syndrome like ST Elevtion Myocardial Infarction. Varasteh-ravan et al. ${ }^{[30]}$ studied the relationship of platelet distribution width in patients with acute STEMI thrombolysed with streptokinase and found that patients with higher platelet distribution width had more risk of thromblysis failure measured by ST segment resolution. PDW can be used as an independent marker of risk of thrombolysis failure and short term mortality in patients with STEMI. 4.4. White blood cells Human white blood cell count is normally 4000 to 11000 cells per microlitre. The most predominant of Conclusion Platelet indices like Mean Platelet Volume (MPV) and Platelet Distribution Width (PDW) are well studied markers to prognosticate patients. It was hypothesized that in acute coronary heart diseae, there is increased platelet swelling and pseudopodia formation which causes an increase 
in the Mean Platelet Volume and Platelet Distribution Width. Among the two indices Platelet Distribution Width is found to be a more specific marker for the activation of platelets. White blood cells are a marker of inflammation and it is also well studied in patients with acute coronary syndrome which causes a rise in the inflammatory markers. White blood cell count, a marker of inflammatory response and platelet distribution width, a marker of reactivity of platelets have been studied to have unfavourable outcomes in patients with ST elevation myocardial infarction. The results of our study has shown significant association between platelet distribution width and white blood cell count with ST segment resolution in patients with STEMI thrombolysed with streptokinase. These factors can be used as simple markers for failure of thrombolysis to suggest an alternative and aggressive management protocol for these patients which require further studies in this context.

\section{References}

1. Kasper, Fauci, Hauser, Longo, Jameson and Loscalzo et al. Harrison's Principles Of Internal Medicine 19th edition. United States Of America. (Mc Graw Hill); volume 2; 1442.

2. Kumar et al. Robbins and Cotran Pathologic Basis Of Disease 7 th edition.( Pennsylvania. Elsevier); 571.

3. Bonow, Mann, Zipes, Libby et al. Braunwald's Heart Disease: A Text Book Of Cardiovascular Medicine 9 th edition. (Philadelphia. Elsevier); 55.

4. Shuja-ur-Rehman, Sheikh S, Nazeer M. ST segment resolution post MI - a predictor of better outcomes. J Pak Med Assoc. 2008 May, 58(5) : 283-6.

5. Salim R. Hamudi Al-Obeidi, Saad H. Ahmedm, Fatma A. Obeid. Evaluation of Platelet Indices in Patients with Acute Coronary Syndrome. Mustansiriya Medical Journal, June,12(1).2013.

6. Lowe GD, Machado SG, Krol WF, Barton BA, Forbes CD. White blood cell count and haematocrit as predictors of coronary recurrence after myocardial infarction. Thromb Haemost. 1985 Oct, 30; 54 (3) : 700-3.

7. Brauwald E. Evolution of the management of acute myocardial infarction: a 20th century saga. Lancet 1998; 352: 1771-4.

8. Amsterdam E A et al. 2014 AHA/ACC Guidelines for the Management of Patients with Non-ST Elevation Acute Coronary Syndromes. Journal of the American College of Cardiology. Sep 2014.

9. Y Birnbaum, B J Drew .The electrocardiogram in ST elevation acute myocardial infarction: correlation with coronary anatomy and prognosis. Postgrad Med J 2003;79:490-504.

10. Maroko P, Libby P, Ginks W, Bloor C, Shell W, Sobel B, Ross JJ. Early eff ects on local myocardial function and the extent of myocardial necrosis. J Clin Invest 1972; 51: 2710-6.

11. Chazov EI, Matveeva LS, Mazaev AV, Sargin KE, Sadovskaia GV, Ruda MI. Intracoronary administration of fibrinolysin in acute myocardial infarct. Ter Arkh 1976; 48: 8-19.

12. Nikhil Sikri, Amit Bardia. A History of Streptokinase use in Acute Myocardial Infarction. Text Heart Inst J 2007;34:31827.

13. Diwedi SK, Hiremath JS, Kerkar PG, Reddy KN, Manjunath CN, Ramesh SS, et al. Indigenous recombinant streptokinase vs natural streptokinase in acute myocardial infarction patients: Phase III multicentric randomized double blind trial. Indian J Med Sci 2005;59:200-7.

14. Michels KB, Yusuf S. Does PTCA in acute myocardial infarction affect mortality and reinfarction rates? A quantitative overview (meta-analysis) of the randomized clinical trials. Circulation 1995; 91: 476-85.

15. Andreotti F, Pasceri V, Hackett DR, Davies GJ, Haider AW, Maseri A. 
Preinfarction angina as a predictor of more rapid coronary thrombolysis in patients with acute myocardial infarction. N Engl J Med 1996; 334: 7-12.

16. Grines CL, Topol EJ, O'Neill WW et al. Effect of cigarette smoking on outcome after thrombolytic therapy for myocardial infarction. Circulation 1995; 91: 298-303.

17. Andreotti F, Patti G. Chronobiology of the haemostatic system. In: Redfern PH, Lemmer B, eds. Handbook of Experimental Pharmacology. Physiology and Pharmacology of Biological Rhythms.( Springer-Verlag, Heidelberg).

18. Andreotti F. Procoagulant and fibrinolytic factors in blood: relation to the pathogenesis and treatment of acute coronary occlusion in man. $\mathrm{PhD}$ thesis, 1992. ISBN 90-5412-006-1. "Relationship Of Platelet Distribution Width And White Blood Cell Count On Admission .. DOI: 10.9790/0853-150802147172 www.iosrjournals.org 172 | Page

19. Mauri F, Maggioni AP, Franzosi MG, et al. A simple electrocardiographic predictor of the outcome of patients with acute myocardial infarction treated with a thrombolytic agent. A GISSI-2 derived analysis. J Am Coil Cardiol 1994;24:6007.

20. Dissmann R, Schr6der R, Busse U, et al. Early assessment of outcome by STsegment analysis after thrombolytic therapy in acute myocardial infarction. Am Heart J 1994;128:851-7.

21. Neuhaus KL, von Essen R, Vogt A, et al. Dose finding with a novel recombinant plasminogen activator (BM 06.022) in patients with acute myocardial infarction: results of the German Recombinant Plasminogen Activator Study (GRECO). J Am Coil Cardiol 1994;24:55-60.

22. Shah A, Wagner GS, Granger CB et al. Prognostic implications of TIMI flow grade in the infarct related artery compared with continuous 12-lead ST- segment resolution analysis. Reexamining the 'gold standard' for myocardial reperfusion assessment. J Am Coll Cardiol 2000; 35(3):666-72

23. Ito $\mathrm{H}$, Tomooka $\mathrm{T}$, Sakai $\mathrm{N}$ et al. Lack of myocardial perfusion immediately after successful thrombolysis. A predictor of poor recovery of left ventricular function in anterior myocardial infarction. Circulation 1992;85(5):1699-705.

24. van 't Hof AW, Liem A, de Boer MJ et al. Clinical value of 12-lead electrocardiogram after successful reperfusion therapy for acute myocardial infarction. Zwolle Myocardial Infarction Study Group. Lancet 1997;350(9078):615-9.

25. Buckley MF, James J W, Brown D E, Whyte G S, Dean MG, Chesterman CN, et al. A novel approach to the assessment of variations in the human platelet count. Throm Haemost 2000;83:480-84.

26. Kaito $\mathrm{K}$, Otsubo $\mathrm{H}$, Usui $\mathrm{N}$ et al. $\mathrm{Br} \mathrm{J}$ hematol 2005;128:698-702.

27. Smith N, Panthansali R, Bath P. Platelets and stroke. Vascular medicine 1999;4:165172.

28. Bath PMW Butterworth R J. Platelet size : measurement, physiology and vascular disease. Blood 1996;7;157-161.

29. O’Malley T, Langhorne P, Elton R, Stewart C. Platelet size in stroke patients. Stroke 1995;26:995-99.

30. Varasteh-ravan H.R., Ali-Hassan-Sayegh S., Mohammad R. Mozayan, Ali Akbar, Karimi-bondarabadi. Relationship of admission mean platelet volume, platelet distribution width and white blood cells with ST resolution in paitents with acute ST segment elevation myocardial infarction treated with strepotokinase without history of previous cardiovascular surgery. Perspectives in Clinical Research. 2013;4:2.

31. Park Y, Schoene N, Harris W, Mean platelet volume as an indicator of platelet 
activation : methodological issues.

Platelets 2002; 13(5-6):301-306.

32. Van der Loo B, Martin JF. A role for changes in platelet production in the cause of acute coronary. Arterioscler Thromb Vasc Biol 1999;19:672-9.

33. Huczek Z, Kochman J Filipiak KJ, Horszczaruk GJ, Grabowski M, Piatkowski R, et al. Mean platelet volume on admission predicts impaired reperfusion and long-term mortality in acute myocardial infarction treated with primary percutaneous coronary intervention. J Am Coll Cardiol 2005;46:284-90.

34. Cetin M, Bakirci EM, Baysal E, Tasolar H, Balli M, Cakici M, Abus S, Akturk E, Ozgul S. Increased Platelet Distribution Width Is Associated With ST-segment Elevation Myocardial Infarction and Thrombolysis Failure. Angiology. 2014 Feb 12.

35. Akashi K, et al: A clonogenic common myeloid progenitor that gives rise to all myeloid lineages. Nature 404:193, 2000.

36. Kumar, et al. Robbins and Cotran Pathologic Basis of Diseases, 7th edition.( Pennysylvania. Elsevier); 663-664.

37. Arnon Blum MD, Julia Sheiman MD, Yonathan Hasin MD. Leukocytes and Acute Myocardial infarction. IMAJ 2002;4: 1060- 1065.

38. Zalokar JB, Richards JL, Blaude JR. Leukocyte count, smoking, and myocardial infarction. $\mathrm{N}$ Engl $\mathrm{J}$ Med 1981;394:465-8.

39. Cole DR, Singian EB, Kate LN. The long term prognosis following myocardial infarction, and some factors which affect it. Circulation 1954;9:321-34.

40. Maisel AS, Gilpin A, Lewinter M, et al. Initial leukocyte count during acute myocardial infarction independently predicts early ventricular fibrillation. Circulation 985;72(3) 414.

41. Furman MI, Becker RC, Yarzebski J, Savegeau J, Gore JM. Goldberg RJ. Effect of elevated leukocyte count on in hospital mortality following acute myocardial infarction . Am J Cardiol 1996;78:945-8.

42. Bagge U, Skalak R, Attefors R. Granulocyte rheology : experimental studies in an in vitro micro flow system. Adv Microcirc 1977;7:29-49.

43. Dormandy J, Ernst E, Matrai A, eta al. Hemorrheological changes following acute myocardial infarction. Am Heart J 1982; 104:1364-7.

44. Barron HV, Cannon CP, Murphy SA, Braunwald E, Gibson M. Association between white blood cell count, epicardial blood flow, myocardial perfusion, and clinical outcomes in the setting of acute myocardial infarction. Circulation 2000;102:2329-34.

45. Diacovo TG, Roth SJ, Buccola JM, eta al. Neutrophil rolling, arrest, and transmigration across activate $d$, surface adherent platelets via sequential action of $\mathrm{P}$ selectin and the beta 2 integrin CD11b/CD18. Blood 1996;88:146-57.

46. Yudkin JS, Kumari M, Humphries SE, Mohammed-Ali V ; Inflammation, obesity, stress and coronary heart disease: is interleukin-6 the link ? Atherosclerosis 2000, 148:209-214.

47. Cannon CP, McCabe $\mathrm{CH}$, Wilcox RG, Bentley HG, Braunwald E: Association of white blood cell count with increased mortality in acute myocardial infarction and unstable angina pectoris. OPUS-TIMI 16 Investigators. Am J Cardiol 2001, 87:636-9, A10.

48. Barron HV, Cannon CP, Murphy SA, Braunwald E, Gibson CM; Association between white blood cell count, epicardial blood flow, myocardial perfusion, and clinical outcomes in the setting of acute myocardial infarction: a thrombolysis in myocardial infarction 10 substudy. Circulation 2000, 102:2329-2334. 